\title{
RECOVERY OF THE FORMAL AND SPATIAL CHARACTERISTICS OF NONO'S VERNACULAR DWELLINGS (ECUADOR) IN CONTEMPORARY CONTEXTS
}

\author{
A. C. Rodriguez ${ }^{1, *}$ \\ ${ }^{1}$ Architecture and Urbanism Faculty, Universidad Central del Ecuador, Av. América - adrodriguez@uce.edu.ec
}

Commission II - WG II/8

KEY WORDS: Dwelling, Interpretation, Space, Form, Contemporary, Vernacular

\begin{abstract}
:
Vernacular architecture contains essential features of identity and customs of a town. Talking about housing, referred as the intimate space of development of a human group, it is understood its cultural significance. Architectural globalization, with features extracted from the outside, adapted without studies in any kind of territory, threatens to absorb those essential qualities of the various villages. Ecuador, as a multicultural country, conceive in the law the conservation of cultural heritage as primordial, however, there are few solutions to the problem of the heritage destruction. Lack of studies avoids the recovery of the built heritage, ignorance of the people downplays the vernacular, where forms and spaces of this architecture have been relegated, despite being the perfect and unique solution for each site. This article expresses the importance of vernacular architecture, its value in memory, and the fight against oblivion. It proposes a solution to curb its disappearance, trying to establish a model for architectural design that revalue the vernacular through an analysis of forms and spaces to suit contemporary contexts. A vision of the present influenced by the past, properly integrated.
\end{abstract}

\section{INTRODUCTION}

There is a way to build that is born when man has the obligation to settle his habitat, thus "arises from the need to build a shelter against the adversities of the environment, from the sedentary nature of man" (Andrés Peñaherrera, 2012). It is called vernacular or popular architecture that does not respond to styles and hardly represents times, but, it is the one that "responds to the needs of its particular user emphasizing its customs, its culture and its essence" (Garabieta, 2010). In addition, this way of building mingles with the environment because it uses materials from the area. It is built without architects, because those who inhabit it are responsible for shaping it. It's "a way to build emanated from the same community, with coherence in style, shape and appearance." (Pesantez, 2011) So, the vernacular architect is one of the most important expressions of a human group that constitutes a trait of identity where customs and traditions transmitted from generation to generation are observed. In 1999, UNESCO declared this architecture as part of the cultural heritage of nations, part of the past that keeps memories and stories that make up the individual, recognizing the indisputable value of it.

Ecuador, with its multicultural nature, gives us a universe of ancient knowledge that have ties to mother earth or "Pacha Mama" in Kichwa ${ }^{1}$ words, forming the essence of what characterizes each person, their history. But this knowledge, this cultural trait, has been affected, expressed in the disappearance of architectural objects, traditions and customs.

On 25 July 2018, in Palembang (Indonesia), "Chocó Andino" territory, located in Ecuador, in the northwest of Pichincha's province, was declared a Biosphere Reserve to join the world wide web in the program Man and the Biosphere (MAB) of UNESCO.

After this statement there begins a process in the Ecuadorian legal framework where ordinances as 137 "(...) established "Chocó Andino" as an area of ecological, cultural and

\footnotetext{
* Corresponding author

Mother language in Ecuador
}

sustainable productive development to the territories of Nono, Calacalí, Nanegal, Nanegalito, Gualea and Pacto." (Quito Metropolitan District, June 22, 2005, p. 1) These villages make up the "Commonwealth of Chocó Andino", a social organizational figure created in 2014, who finds support in this legal framework to preserve its territory. Within this process they begin to consider new strategies for the development of Territorial Planning Plans and research initiatives are created supported by the academy ${ }^{2}$ who analyses the territory focused on urban and social development. However, these initiatives doesn't include an architectural study in the settlements, despite of being essential for cultural heritage. The vernacular architecture is part of Chocó Andino's social value, increasing the importance of the Reserve for the country.

Thus, this study takes place in Nono parish, a populated area that, at present, has been threatened their features of identity through globalizing processes in that place.

\section{DEVELOPMENT}

The dwelling, also called house or residence, since its inception, in all times and regions, has been the response to the demands of human security and weather protection.

For Margalef Arce (2009) house refers to the physical and symbolic space in which man lives, and where the action of living is part of the reside in one place, erecting it as the main attribute of being, an identity and formal passport. With this precision can be said that a house in not only defined as the physical form that welcomes human life and protects it, but "the inhabit, in its intimate and primary form, requires the ownership of the place, accept it as that space where develops it daily life" (Heidegger, 2014).

The revised definitions are perfectly linked with that architecture called vernacular, theme recurring for

\footnotetext{
2 Territorial Observatory of Production, within the Faculty of Architecture and Urbanism of the Central University of Ecuador developed in 2018 the research "Rural Territories: Commonwealth Chocó Andino"
} 
anthropologists and other experts related, but only since the twentieth century, with the presentation of Bernard Rudofsky "Architecture Without Architects" at the Museum of Modern Art of New York (1965), it recognizes its social and environmental value.

This conceptualization is formalized through the ICOMOS $^{3}$ in its letter $\operatorname{CIAV}^{4}(1999)$ with parameters that allows to clearly identify such expressions. Thus, the architecture is defined as vernacular if it is:

- One way to build emanated from the community itself.

- A recognizable local or regional character linked to the territory.

- Architecture with coherence of style, shape and appearance, as well as the use of traditionally established building types.

- Traditional wisdom applied in the design and construction which is transmitted informally.

- A direct response to functional, social and environmental requirements.

- The application of systems, traditional crafts and skills.

As can be seen, customs, traditions, and ancestral knowledge inherited in a community are the inherent attributes of this type of architecture. It has a historical-cultural side and, together with an effective reading of the territory, uses the resources of the area, considering geographic, climate, and natural aspects such as flora and fauna to get an efficient adaptation, manifesting the identity of those who inhabit it. So, the popular, indigenous without architects, architecture is what builds landscapes, evokes memory, maintains traditions and exemplifies customs. It is the one that is not kept static, but every day sees its developments under the advancement of those who conceive it. And it is also one that is threatened against oblivion, disappearing due to the advance of modernity and the hegemony of the constructive paradigms posed by globalization. This architecture is overwhelmed by the socalled "global architecture" that is the result of an accelerated process does not contemplate the reality of the area, acquiring visual and constructive information elsewhere, built by some and inhabited by others.

Despite the importance of this architecture represents, there are countless villages in Ecuador where real estate in this category have been damaged, either by neglect or intentional acts that promote its destruction. The importance of preserving such expressions through statements of Cultural Heritage of a nation, strengthening its inherent historical character and appealing to the collective memory to maintain intact its value in the minds of people, is then determined.

In the case of Ecuador, inside the legal framework and through the so-called Emergency Decree of the Cultural Heritage, in 2008, the former President Rafael Correa launched new plans to monitor and evaluate the architecture of the country. This is how some building acquired the status of heritage for the first time, while many others were examined, highlighting problems of deterioration and abandonment.

As for the context, the study area is Nono, at 2724 meters above sea level, is located in the mountain area, $18 \mathrm{~km}$ from Quito. With an area of $21359 \mathrm{~km} 2$ on the slopes of the Pichincha volcano, Nono is formed as one of the rural territories of great importance to the province.

\footnotetext{
${ }^{3}$ International Council on Monuments and Sites.

${ }^{4}$ Charter on the Built Vernacular Heritage (1999).
}

It is a territory whose productive and social system is linked to the natural environment, with a sparse population, low densities with 8 inhabitants per $\mathrm{km} 2$, and negative growth. The settlers, according to official data $^{5}$, are engaged in agricultural, livestock, forestry, local trade and tourism activities.

Historically, it retains vestiges of pre-Columbian features with pre-Incan cultures as Yumbos, Niguas and Tiguas. Whereafter large cattle farms were emplaced, and then, divided into huasipungos ${ }^{6}$. The current Nono develops like that settlement near the capital, direct communication with other parishes as Calacalí and Tandayapa, where its irregular urban morphology is immersed in the natural landscape.

The people of the parish, identified as mestizo ethnic group, have expressed their customs and traditions in festivals, gastronomy, and buildings in the area. Especially in this, miscegenation has manifested itself as a symbiosis of construction techniques, forms, and materials of America and Europe, a mix of American masma, the Cañarí or Puruhá ${ }^{7}$ house, and courtyard Spanish house. So, a style emerges with indigenous and Spanish colonial characteristics from the different historical periods.

This architecture enhances its cultural and social value recognized as part of the nation's immovable heritage in 1990, with the inscription of 21 buildings in Nono that present morphological, typological and technical-construction characteristics that justify their inclusion in the government inventory. This catalog is updated in 2006 reviewing the state of conservation of declared properties and analyzing new cases for inclusion. Here is where the problem is showed because, although there is interest in this architecture, many vernacular buildings have been tapped or even replaced entirely with contemporary techniques of other places without analysis criteria, undermining the appearance of the parish and the cultural identity of the area.

At this time, the building process of the parish is made without studies of current needs. Nono's inhabitants no longer see in the vernacular an effective response to their way of living, and aggravated by the massive population migration, has caused irreparable losses in the cultural built heritage. The threat of apparent "modern era" to the vernacular architecture, its spaces and its forms, is derived from the little knowledge about its features and how to apply them in contemporary buildings to meet the needs of today's residents, maintaining the architectural language of the area. The advancement of technology and a changing society is undeniable and unstoppable, but finding a point in common between these two architectures will allow us to preserve and value characteristic aspects of Nono.

So, how do you keep identifying features, boosting the rescue of the culture of the town by the new architectural offer? This study presents an answer that allows match the traditional architecture with the contemporary context, effectively solving the demands of new ways of living. Based on this question arises the need to position the analysis aspects for understanding all of the architectural concept in a building, where the form and space categories can be essential for this.

\footnotetext{
52010 Census. National Institute of Statistics and Censuses.

${ }^{6}$ Portion of land that the landowner gives to his worker.

7 Pre-Inca cultures of Ecuador.
} 
The form is important because it's the externalized architectural expression, which gives identity making distinguishable through their various properties. "(...) Form suggests reference to the internal structure, to the outer contour and to the principle that confers to the whole unit "(Ching, 2010, p. 34). On the other hand, the architectural space carries a "strong link with activities developed in it", (Sierra, 2012), where you can perform both social and morphological analysis of the architectural object, because its setting, its relationship, the way to stand in place, among other features, is a direct expression of who conceived, but also who makes use of it.

For proper analysis of these concepts applied to vernacular houses Rodriguez's (2017) methodology is used. It applies an observation and deduction process based in shape and space parameters provided by F. Ching (2010), in addition, it uses considerations issued by the Charter on the Built Vernacular Heritage by ICOMOS-CIAV from UNESCO.

The methodology is divided into five stages, the first being the selection of a sample of households, to continue the development of the inventory form, working with the model of the National Institute of Cultural Heritage, but adding data such as elevations and floor plans, stylistic characterization, visual aspects of the facades, and condition of the elements. Then it defines architectural typologies, which brings together a number of houses that have similar shape and spatial characteristics. After that, an analysis of spatial function defining the uses that articulate each typology. Therefore, it continues with formal analysis, which examines those aspects that Ching (2010) presents in its work "Architecture, form, space and order". With these assumptions, and the identification of typologies the methodology presents the respective reflections and conclusions.

In order to start the study, population is taken as the 22 buildings with Immovable Heritage declaration by the "Instituto Metropolitano de Patrimonio" in Nono. However, the statement does not guarantee that all buildings had the character of vernacular so each one is reviewed with all the parameters described by the CIAV, based on observation techniques and interviews with users. As a result of the process 13 properties are suitable to be considered for the study.

With this information, the individual analysis begins in each building with an information sheet composed of diagrams, pictures, drawings and architectural texts that support the study of the houses. The development of functions relation to each space and the projection of these respect of the volumetric form and its immediate context are described in every sheet. At the end of the analysis, a tabulation of results is performed, comparing them to each other by observing several similarities in form and space characteristics. So, it is considered appropriate to define architectural typologies that facilitates the reading of vernacular housing models found in Nono.

\subsection{Type 1: Hacienda type house.}

It is a rectangular or quadrangular volume with two storeys located in an isolated way on the urban grid, at the intermediate on the lot and articulates its shape by addition exercise.

The various facades are worked with guiding principles of symmetry and rhythm, where the whole set rises from the ground on an artificial horizontal plane that create a high level and facilitates the interior space development. In turn, the principal facade that is offered to the street stands out, and in its front has decoration that refers to typical houses of colonial architecture in Quito's historic center. It has the implicit mark from the field, such as columns with rectangular decorative moldings upper and lower, balconies with balustrades and railings, wooden sills on the windows and continuous shot moldings which visually separate the two storeys of the building.

The segmented arch accompany by rectangular windowsills is how the openings cut the continuity of the walls in order to obtain interior light. However, these do not exceed of $25 \%$ over the size and proportion of the walls, affecting the entry of sun light and creating dark and gloom interior spaces, but keeping the internal temperature at favorable levels (Figure 1).

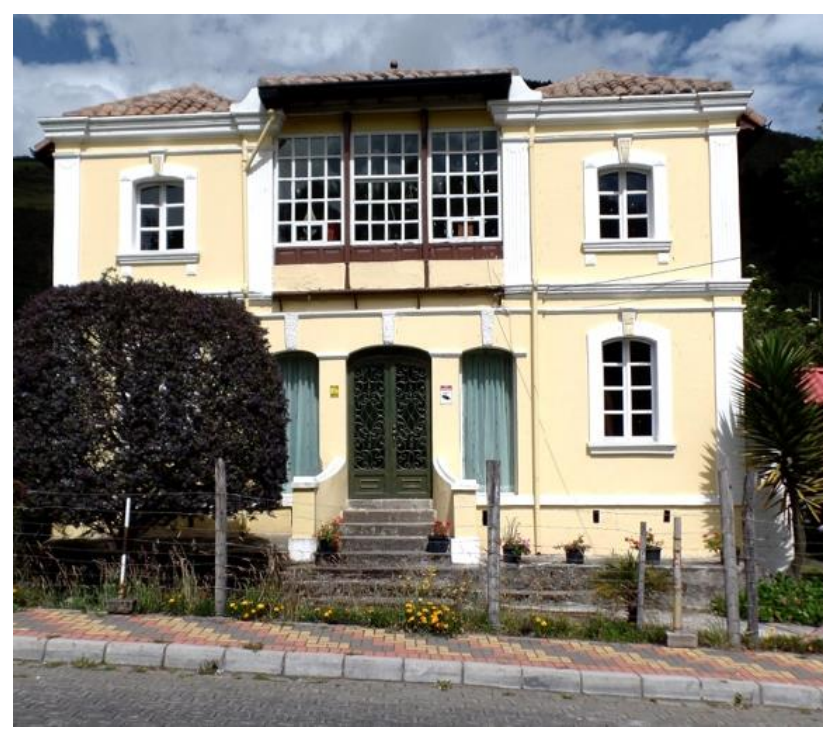

Figure 1. Hacienda type house, Nono, Ecuador, 2019.

With a continuous internal circulation that connects the front to the back of the property, it develops spaces grouped together where only have stairs, interior or exterior, as spaces designated for the specific function of communicate.

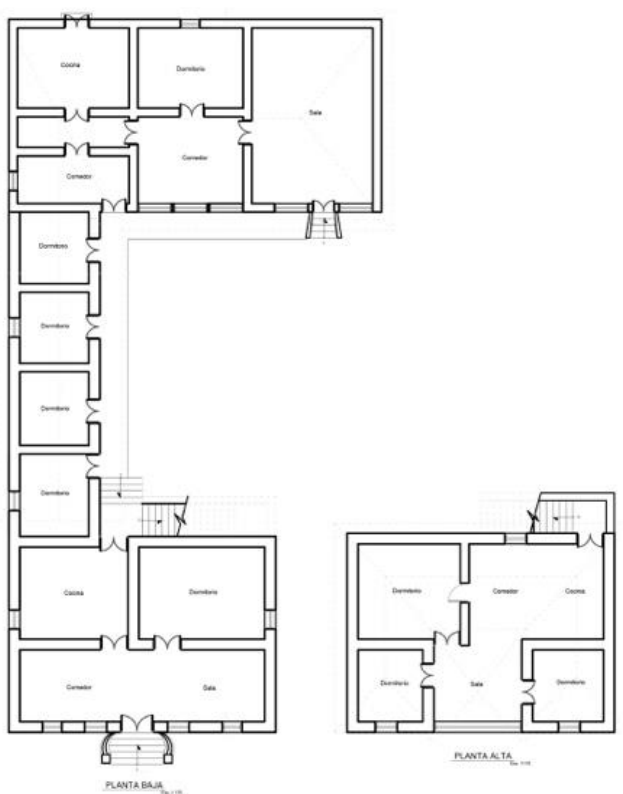

Figure 2. Internal distribution, Hacienda type house, Nono, Ecuador, 2019. 
It stands out the socio-peto ${ }^{8}$ spaces in relation to socio-fugo ${ }^{9}$ spaces, where these are precisely the spaces that works like distributors because the houses doesn't have spaces designated for circulation. They are characterized by poor indoor-outdoor relationship, and this is only done by openings designated to entry and exit.

Finally, the building is topped by a tile pitched roof, with eaves and decorated modillions on almost all fronts, and two to four inclinations (Figure 2).

\subsection{Type 2: Porch Type House.}

This type of house stands out for the simplicity of the rectangular volume in one storey, in adition, it's identified for being continuous in the urban grid, intermediate or corner at the lot. This type house creates its own horizontality against the natural slope of the ground with an artificial level, keeping the identity of the initial volume, which is only modified through a subtraction exercise to generate the porch.

The Porch House expresses its form straight edges and pure facades, without decoration, where only articulates some façade's elements by symmetry and rhythm. The front elevation differs from the other because of the presence of a porch, a social open space covered by the roof of the building. The cantilever roof that covers the portal is supported by wooden pillars with a trapezoidal top piece with curved edges. The porch is surrounded by wooden railings, however, these used to be replaced by halfway-up masonry, closing the visual of the porch and leaving only a space for entry and exit of users.

As for the openings, windows and doors are rectangular and are placed on the different facades of the house following principles of symmetry. They are double hinged, but windows stand out for their small dimensions that foster a sense of continuity in the walls, with a ratio of up to $30 \%$ of the empty with respect to the full facade, creating interiors with little input light and ventilation. The house ends with a tile pitched roof, with two to four inclinations, its structure is made of wood and covered with baked clay tiles. The roof has eaves in all edges and the presence of modillions as the end of beams and joists (Figure 3 ).

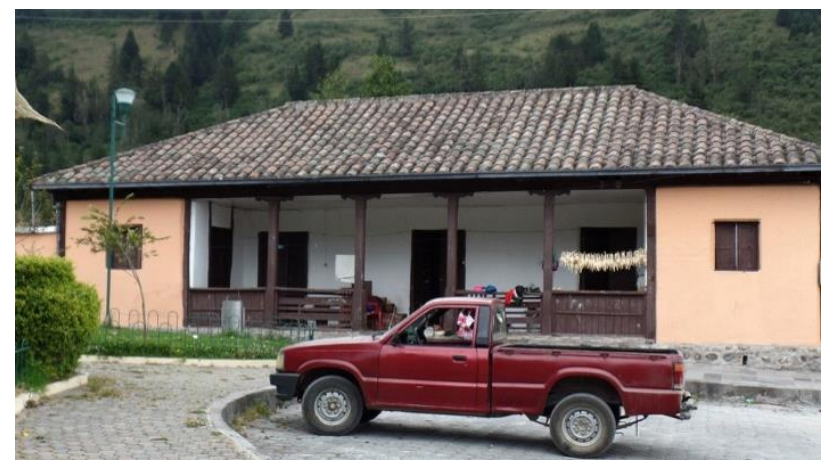

Figure 3. Porch type house, Nono, Ecuador, 2019.

Spatially, it stands out for promoting circulation through spaces for other activities, connecting the inside to the outside through doors at the front and lateral elevations, designating the sociopeto spaces as distributors. The portal is used as a distributor space for the house as well, multidirectional, and frames the

Spaces that provide the relationship between users

9 The guidelines of the space express such fluidity that they avoid the relationship of the user to each other. entrances to the different areas of the house. It allows and complement agricultural activities since many users use them to dry seeds or other product (Figure 4).

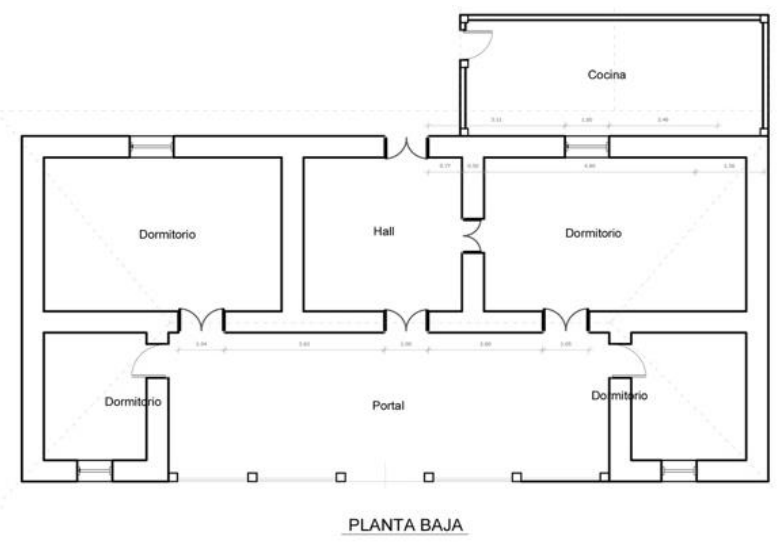

Figure 4. Interior distribution Porch type house, Nono, Ecuador, 2019.

\section{3 - Type 3: Continuous Opening Type House.}

This typology is the evolution and adaptation of the features presented in the buildings of the above types and based on the needs of the people. It is a rectangular volume, developed in one storey, presented in continuous way in the urban grid, and in intermediate way on the lat. It is placed on an artificial high level of the floor to overcome the natural slope of the ground.

As for the facades, the front stands out because of the presence of decorative elements like reliefs framing edges of the volume through false columns in contrasting tones, without further details. The elements located on the main facade are articulated with exercises of symmetry.

Regarding the openings, this type stands out for having an opening defining windows and a door. The form of this opening is the evolution of the portal in the original building, which was modified by placing halfway up masonry, as seen in the homes of the above type, and finally the remaining height is closed with windows, then place an entry door, eliminating the gantry. These windows are divided by a wood reticle to separating the glass sheets, and are placed on each side of the rectangular door which is the main entrance. These empty generate higher proportion of vacuum against the full in facade, achieving percentages of $30 \%$ and $40 \%$. The rest of the openings are rectangular, small in size and are in the other facades of the house. The roof, hipped, maintains eaves and modillions on all fronts, but it has an attic framing the entrance door. This element, in most cases, has a window that allows the entry of light into the houses (Figure 5).

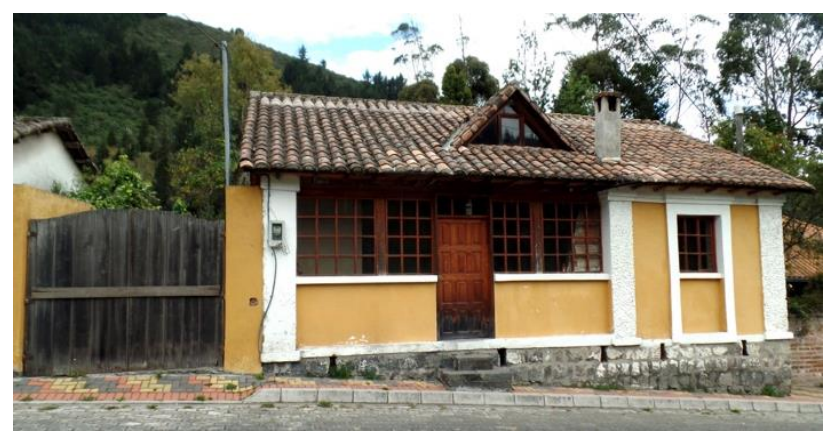

Figure 5. Continuous Opening type House, Nono, Ecuador, 2019. 
The inner spatiality is articulated in grouped form where the connection front - rear is prioritized through openings with continuous circulation. The space character is the multidirection, there are no those designated for circulation only. Its use is defined by the users themselves being quite variable functions (Figure 6).

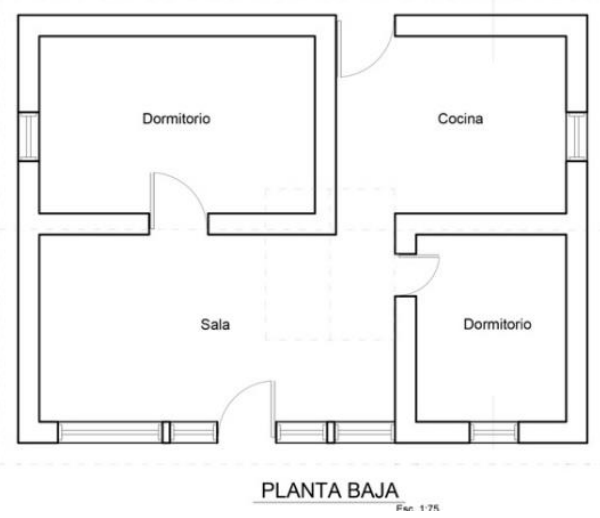

Figure 6. Interior distribution Continuous Opening type House, Nono, Ecuador, 2019.

After determining these types, those characteristics that make the essence of the settlement, are extracted based on the relevance for this study, and they are:

- Pure forms: Refers to the main volume of the homes. They are volumetric bodies that possess integrity in their edges. It doesn't have gaps or interruptions, protruding or retract elements, making visual and formal continuity of volumetric. Thus, the rectangular or quadrangular prisms are used, where despite the removal of some of its parts, the edges remain the same distance and continuity, thereby maintaining the identity of the shape.

- Openings: referring to the openings in the walls. Nono, whether doors or windows, is possible to observe small openings in proportion to the masonry in which they are located because of the construction system. It stands out the segmental arch in the form, providing a decorative character to the facade. However, $62 \%$ of the studied buildings have rectangular openings, of simple shapes, which reinforce the purity of the volumes.

- Decorative Reliefs: This refers to those forms superimposed on the facades, whose only function is aesthetic. Highlight openings and edges of the volume and contrast with the rest of the facade for its location and its base color.

- Columns cap: These are the pieces that are located at the end of the structural wooden pillars. Present in all the portal type houses in order to hold the cantilever roof that cover it. They are trapezoidal elements with curved or rectangular ends, and inner decorative carving (Figure 7).

- Modillions: Those structural elements that make part of the roof and are seen in the eaves of buildings that possess them. They have trapezoidal shape with curved tops, highlight its simplicity in form (figure 8).

- Roofs: In general terms, have several falls, however, are common two and four inclinations. With baked clay tile, all roofs have eaves. None of them has slope greater than $40 \%$.

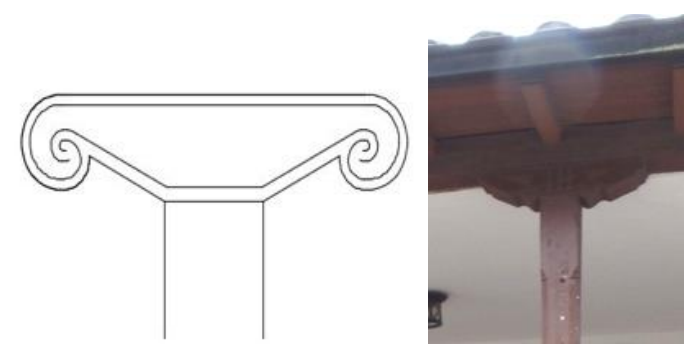

Figure 7. Column Cap, Nono, Ecuador, 2019.

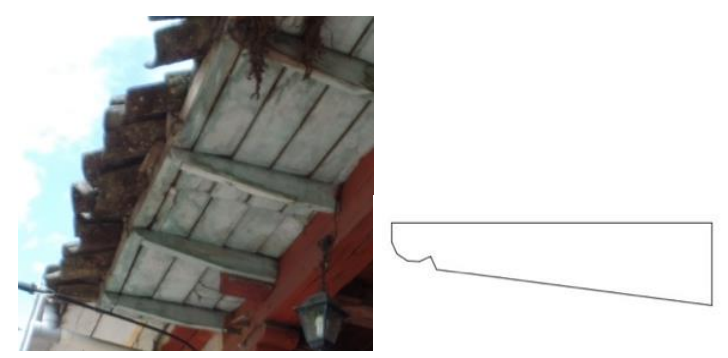

Figure 8. Mondillions, Nono, Ecuador, 2019.

About the elements that characterize the space they are:

- The portal or porch: Result of subtracting part of the overall volume, is a covered and open space, supported by wooden pillars, that enables communication with the outside users. It is a recreational space where house's users spend their time and exchange moments with passersby. It's also used to dry leaves and seeds of agricultural products for later consumption.

- Functional spaces: spaces that make the homes of Nono are defined by the function is performed on them, so private areas are the bedrooms and the public spaces are the living room, dining room and kitchen.

- Circulations: The houses do not have spaces designated exclusively for horizontal movement, so this is done through others with different functions. The vertical movement for those units of two storeys is performed through a staircase, which is located inside or outside of the house.

- Toilets: spaces like bathrooms or laundry are located completely detached from the rest of the functional spaces inside the houses, and take their place on the outside thereof.

In order to continue generating data to help to properly display the architectural panorama of Nono, the building systems are observed quickly, finding methods of building land as adobe and rammed earth. In other hand, structural systems are analyzed finding a load-bearing wall system where floors and roofs are resolved with wooden structures and the roof coated with baked clay tile.

Incidentally, based on interviews of current users in the buildings, the needs of habitability are defined, stating, first, the high cost of maintenance of earth building systems, the lack interior natural lighting and therefore, lack of ventilation. Another issue of preponderance is discomfort of place the toilets outside the houses and intimacy lacking in certain areas with private activities due to the lack of spaces specifically designated for circulation. 


\section{CONCLUSIONS}

The problem of architectural globalization is common in many rural communities of Ecuador. Gradual loss of native architecture has to do with the current disengagement and uprooting of diverse populations with respect to their roots as well as little sense of ownership with the territory. There are varied causes of these problems, however, as part of the formation of architects, it is the hands of various professionals give value to what really identifies a social group, that essence that makes it unique and makes part of the cultural baggage, as reinforcement of collective memory.

Constant technological innovations and the evolution of living ways create unequal competition with those traditional building systems that generated spaces of continuous communication with the inhabitant and community. Therefore, the focus of current research is to rescue the advantages possessed by these systems, recognize their value and achieve communicate that past with the present.

This research develops a model of architectural study based on observation of formal exercises that gave rise to the different facades of vernacular architecture, combined with the spatial interpretation regarding the opinions collected from users who reside there. This shows the link of this architecture with the territory in which it is located. as well as the features of the worldview of the authors, reflected in decorations, vacuum and full. The adjustments that these buildings have suffered since birth also stands out, being adapted for current uses demanding individuals, even resulting in a new type house that currently is part of the urban landscape of the area. Finally, the essential characteristics that make up the vernacular architectural landscape in Nono are determined, granting a correct vision of the buildings in the area and their cultural value.

This analysis allows precedent for the future building development of the town, where, through methods such as Vázques Piombo (2016) models, generated contemporary syncretic houses adapted to a heritage context, developed with exercises that allows interpret morphological architectural manifestations presented here. Thus, it is expected that, with various of these exercises, new architectural paradigms are settled, developing buildings with conscious projections of their environment and the social context where they are located, taking into account the essential features of the human group that it intended to host. A more humane and identity architecture.

\section{REFERENCES}

Casanova Poveda, R. I., 2011. Análisis de la tendendencia de la construcción de la vivienda en Ecuador. Años 2005 a 2010. Guayaquil: Universidad de Guayaquil

Ching, F., 2010. Arquitectura Forma, Espacio y Orden. Barcelona: Gustavo Gil.

Ekambi - Schmidt, J., 1978. La percepción del habitat. Barcelona: Gustavo Gili.

Engels, F., 1884. El origen de la familia, la propiedad privada y el estado. Moscú: Archivo Marx.

Garáte Rojas, I., 1993. Artes de la cal. Madrid: Min. de Cultura.

Garabieta, L., 2010. Habitat Vernáculo, un safari en el tiempo. Buenos Aires: Nobuko.
Gobierno Autónomo Descentralizado de Nono, 2015. Plan de Ordenamiento y Desarrollo Territorial de Nono. Distrito Metropolitano Quito, Pichincha, Ecuador: Publicación propia.

Gobierno de la República del Ecuador, 2019. Presidencia de la República del Ecuador. Obtenido de https://www.presidencia.gob.ec

Heidegger, 2014. Construir, habitar y pensar. Barcelona: La oficina.

Instituto Metropolitano de Patrimonio, 2018. Actualización 6 inventarios correspondientes a 12 parroquias rurales y urbanas del $D M Q$. Quito: Secretaría del Consejo.

Instituto Nacional de Estadísticas y Censos, 2010. Ecuador en Cifras. Ecuador. ecuadorencifras.gob.ec/institucional/home/

Martín Galindo, J. L., 2013. La arquitectura vernácula: patrimonio de la humanidad. Alicante: Biblioteca Virtual Miguel de Cervantes.

Margalef Arce, M., 2009. Dificultad en la búsqueda moderna de habitar. España: Editorial española.

May, J., 2011. Casas hechas a mano y otros edificios tradicionales de arquitectura popular. Barcelona: Art Blume.

Muñoz Serra, V. A., 2012. El espacio arquitectónico. España: Universidad de Concepción.

Muxi, Z., H. Falagan, D., Montaner, J. M., 2012. Herramientas para habitar el presente. La vivienda del siglo XXI. España: Universidad de Cataluña.

Observatorio de la Producción Territorial, 2018. Mancomunidad Chocó andino. Manual para sus habitantes. Quito: Observatorio de la Producción Territorial.

Peñaherrera, A., 2012. Introduccion a la historia ecuatoriana y Occidental de la Arquitectura y del Urbanismo. Quito: Universidad Central del Ecuador. Editorial universitaria.

Pesántez, M., 2011. La Arquitectura Popular y Vernácula en las Provincias de Azuay y Cañar. Arquitectura tradicional en Azuay y Cañar Técnicas, creencias, prácticas y saberes. Azuay, Ecuador: INPC.

Ruskin, J., 2012. Las siete lámparas de la arquitectura. México: Coyoacán.

Silva, N. J., 2013. El patrimonio vernacular, fuente de saberes tecnológicos y sostenibilidad. Actas de Congreso Taller Sur (págs. 175-185). Valdivia: Universidad Austral.

Vásques Espi, M., 2001. Construcción e impacto sobre el ambiente: el caso de la tierra y otros materiales. Madrid: Ed. propia.

Vargas, J. F., Brito, D. E., 2002. Estudio y valorización de la vivienda vernácula rural de la provincia de Loja. Loja.: Universidad de Loja

Vázquez Piombo, P., 2016. Arquitectura contemporánea en contextos patrimoniales. Una metodología de integración. Guadalajara: Inst. Tecn. y de Estudios Superiores de Occidente.

Velecela Serrano, M., 2008. Arquitectura vernácula del Pachamama al Cojitambo. Cuenca, Ecuador: Univ. de Cuenca.

Distrito Metropolitano de Quito, 2005. Ordenanza 137. Quito, Ecuador: Secretaria de Consejo. 